\title{
Acclimation of Solea senegalensis to different ambient temperatures: implications for thyroidal status and osmoregulation
}

\author{
Francisco J. Arjona • Ignacio Ruiz-Jarabo • \\ Luis Vargas-Chacoff • María P. Martín del Río • \\ Gert Flik · Juan M. Mancera · Peter H. M. Klaren
}

Received: 9 June 2009/ Accepted: 15 February 2010/Published online: 3 March 2010

(C) The Author(s) 2010. This article is published with open access at Springerlink.com

\begin{abstract}
We have investigated the regulation of thyroidal status and osmoregulatory capacities in juveniles from the teleost Solea senegalensis acclimated to different ambient temperatures. Juveniles, raised in seawater at $19^{\circ} \mathrm{C}$, were acclimated for 3 weeks to temperatures of 12 , 19 and $26^{\circ} \mathrm{C}$. Since our preliminary observations showed that at $12^{\circ} \mathrm{C}$ feed intake was suppressed, our experimental design controlled for this factor. The concentration of branchial $\mathrm{Na}^{+}, \mathrm{K}^{+}$-ATPase, estimated by measurements of enzyme activity at the optimum temperature of this enzyme $\left(37^{\circ} \mathrm{C}\right)$, did not change. In contrast, an increase in $\mathrm{Na}^{+}, \mathrm{K}^{+}$ATPase activity (measured at $37^{\circ} \mathrm{C}$ ), was observed in the kidney of $12^{\circ} \mathrm{C}$-acclimated fish. In fish acclimated to $12^{\circ} \mathrm{C}$, the hepatosomatic index had increased, which correlated with increased plasma levels of triglycerides and nonesterified fatty acids. Plasma cortisol levels did not differ significantly between the experimental groups. In liver and gills, the amount of iodothyronine deiodinases that exhibit
\end{abstract}

Communicated by H. O. Pörtner.

F. J. Arjona ( $)$ · I. Ruiz-Jarabo · L. Vargas-Chacoff .

M. P. Martín del Río · J. M. Mancera

Centro Andaluz Superior de Estudios Marinos, Facultad de

Ciencias del Mar y Ambientales, Departamento de Biología,

Universidad de Cádiz, Av. República Saharahui s/n,

11510 Puerto Real, Cádiz, Spain

e-mail: F.arjona@science.ru.nl

F. J. Arjona - G. Flik · P. H. M. Klaren

Institute for Water and Wetland Research,

Faculty of Science, Department of Animal Physiology,

Radboud University Nijmegen, Heyendaalseweg 135,

6525 AJ Nijmegen, The Netherlands

L. Vargas-Chacoff

Instituto de Zoología, Facultad de Ciencias,

Universidad Austral de Chile, casilla 567, Valdivia, Chile thyroid hormone outer ring deiodination was up-regulated only when fish did not feed. When assayed at the acclimation temperature, kidney deiodinase activities were similar, indicating a temperature-compensation strategy. 3,5,3'-triiodothyronine (T3) tissue concentrations in gills and kidney did not differ significantly between experimental groups. However, at $12^{\circ} \mathrm{C}$, lower $\mathrm{T} 3$ tissue levels were measured in plasma and liver. We conclude that S. senegalensis adjusts its osmoregulatory system to compensate for the effects of temperature on electrolyte transport capacity. The organ-specific changes in thyroid hormone metabolism at different temperatures indicate the involvement of thyroid hormones in temperature acclimation.

\section{Introduction}

Temperature is a pervasive environmental factor. In fishes, ambient temperature greatly determines physiological processes such as oxygen consumption (Binner et al. 2008), growth (van Ham et al. 2003), energy metabolism (Couto et al. 2008; Enes et al. 2008) and osmoregulation (Metz et al. 2003; Fiess et al. 2007; Sardella et al. 2008). In particular eurythermal ectotherms, amongst which are many fish species, encounter considerable variations in ambient and body temperatures, and must have adapted by developing adequate acclimation strategies.

The Senegalese sole (Solea senegalensis, Kaup 1858) is a euryhaline flatfish that tolerates salinities from 5 to $55 \%$ (Arjona et al. 2007). The species is distributed from the Bay of Biscay to the southern Atlantic off Senegal, and the western basin of the Mediterranean Sea. In nature, juvenile S. senegalensis density is relatively high in water temperatures between 13 and $28^{\circ} \mathrm{C}$ where they mainly feed on 
polychaetes (Vinagre et al. 2006). In Spain, aquaculture of $S$. senegalensis is carried out in estuarine ponds that are exposed to wide variations of temperature $\left(12-26^{\circ} \mathrm{C}\right.$ annually). Osmoregulatory and thyroidal responses to osmotic challenges have been analysed previously (Arjona et al. 2007, 2008) and point to coordinated interactions between cortisol and thyroid hormone. However, there is no information available on the effects of ambient temperature on osmoregulatory capacity and thyroidal status in this species.

The thyroid gland in teleostean fishes mainly secretes the prohormone thyroxine (T4). Enzymatic outer ring deiodination (ORD), catalyzed by deiodinases, is required to obtain the bioactive thyroid hormone $3,5,3^{\prime}$-triiodothyronine (T3). As in mammals, two types of deiodinases with ORD activity have been described in fish: deiodinase type 1 (D1) and type 2 (D2), which are mainly expressed in gills, liver and kidney. Their deiodination capacity is an important determinant of the circulating levels of thyroid hormones, which define the thyroid status in teleosts (Eales and Brown 1993).

The bioactive hormone T3 is truly pleiotropic. In fishes, thyroid hormones are involved in somatic growth, metamorphosis, parr-smolt transformation and reproduction (Eales 2006). Several studies have shown that thyroid hormones stimulate basal metabolic rate and oxygen consumption in teleostean tissues (Peter and Oommen 1989; Lynshiang and Gupta 2000). It can thus be anticipated that, in teleosts, thyroid hormones play a role in the adjustment of energy expenditure to different energy demands imposed by different temperatures. Moreover, changes in acclimation temperature affect fish thyroid function profoundly (Eales and Brown 1993; Cyr et al. 1998; van den Burg et al. 2003), as temperature positively correlates with plasma thyroid hormone levels and clearance rates (reviewed by Eales 1985).

In osmoregulatory organs such as gills and kidney, the $\mathrm{Na}^{+}, \mathrm{K}^{+}$-ATPase pump is an important determinant of osmoregulatory capacity (Marshall and Grosell 2005). Cortisol is involved in fish osmoregulation, and thyroid hormones have been proposed to exert a supportive, permissive role for cortisol action (McCormick 2001). The exact role of thyroid hormones in osmoregulation is not yet fully elucidated, however (Evans 2002; Klaren et al. 2007).

In this study, we have investigated osmoregulatory and thyroidal aspects of $S$. senegalensis acclimated to temperatures that are encountered by this species in aquaculture.

\section{Materials and methods}

Animals and general procedures

Juvenile Senegalese sole were provided by Planta de Cultivos Marinos (C.A.S.E.M., Universidad de Cádiz, Puerto
Real, Cádiz, Spain). Fish were transferred to the wet laboratories at the Faculty of Marine and Environmental Sciences (Puerto Real, Cádiz, Spain) and kept for 14 days in 400-1 tanks in a flow-through system containing seawater of $38 \%$ salinity and under natural temperature $\left(19^{\circ} \mathrm{C}\right)$ and photoperiod (May, 2007) until the start of experimental procedures. Fish were fed daily at 09:00 a.m. with commercially available dry pellets (Dibaq-Diproteg SA, Segovia, Spain) at a ration of $1 \%$ of the total body weight. During the experiments (performed in May-June 2007), fish were kept in 400-1 tanks containing recirculating water at temperatures of 12,19 and $26^{\circ} \mathrm{C}$, respectively. Salinity was maintained at $38 \%$ in all experimental groups. Water quality parameters (hardness, and levels of $\mathrm{O}_{2}, \mathrm{CO}_{2}, \mathrm{H}_{2} \mathrm{~S}$, $\mathrm{NO}_{2}^{-}, \mathrm{NO}_{3}^{-}, \mathrm{NH}_{4}^{+}, \mathrm{Ca}^{2+}, \mathrm{Cl}_{2}$, suspended solids) were monitored continuously throughout the experiment: no major changes were observed.

Preliminary study: feed intake at $12^{\circ} \mathrm{C}$

Since several authors have reported on the inhibitory effect of low temperatures on feed intake in different teleost species, including flatfish (Imsland et al. 2007; Handeland et al. 2008), we decided to first investigate feed intake during acclimation to low ambient temperature $\left(12^{\circ} \mathrm{C}\right)$ in S. senegalensis. Juveniles of $19^{\circ} \mathrm{C}$-acclimated animals ( $n=5,62 \pm 3 \mathrm{~g}$ body weight) were transferred to a tank where the water temperature was decreased by $1^{\circ} \mathrm{C}$ per day (the new daily temperature was always adjusted at 14:00 h). When water temperature had reached $12^{\circ} \mathrm{C}$, fish were kept at this temperature for 3 more weeks. Feed intake decreased when water temperature was lower than $15^{\circ} \mathrm{C}$. At $12^{\circ} \mathrm{C}$, although animals were given a daily ration of $1 \%$ of the total body weight, fish did not react to the feed provided and did not feed.

Acclimation and exposure to different ambient temperatures

Juvenile Senegalese sole ( $n=40,69 \pm 2$ g body weight) were caught by netting, lightly anaesthetized in $0.05 \%(\mathrm{v} / \mathrm{v})$ 2-phenoxyethanol, weighed and randomly divided into 4 groups ( $n=10$ animals per group). The groups were transferred to tanks with a nominal water temperature of $19^{\circ} \mathrm{C}$. Two tanks were maintained at $19^{\circ} \mathrm{C}$. In the two other tanks, temperature changed gradually by $1^{\circ} \mathrm{C}$ per day from 19 to 12 or $26^{\circ} \mathrm{C}$ to allow animals to acclimate. As the results of our preliminary experiment showed that fish kept at $12^{\circ} \mathrm{C}$ did not feed, we included a fasting control by depriving one group kept at $19^{\circ} \mathrm{C}$ of feed. Following the 7-day acclimation period, fish were exposed for 3 weeks to the different ambient temperatures and feeding regimes. Earlier results show that a period of $2-3$ weeks is sufficient 
to reach complete acclimation and a new steady state in eurythermal teleosts (Campbell and Davies 1975; Goldspink 1995). Animals were euthanized at 09:00 a.m., i.e. immediately prior to their daily feeding time, and samples were collected as described in the next paragraph.

\section{Sampling procedures}

Fish were netted and deeply anaesthetized in $0.1 \%(\mathrm{v} / \mathrm{v})$ 2-phenoxyethanol, weighed and sampled. Mixed arterial and venous blood was collected from the caudal peduncle in 1-ml heparinized syringes. Plasma was obtained by centrifugation ( $3 \mathrm{~min}$ at $10,000 \mathrm{~g}$ ), immediately frozen in liquid nitrogen and stored at $-80^{\circ} \mathrm{C}$ until analysis of plasma parameters. Fish were then killed by spinal transection. From each fish, the first gill arch on the ocular side was excised as well as a small portion of the posterior zone of the kidney using fine-point scissors. Tissues were blotted on absorbent paper to remove excess water, frozen in liquid nitrogen and stored at $-80^{\circ} \mathrm{C}$ until analysis of $\mathrm{Na}^{+}, \mathrm{K}^{+}$ATPase activities. Liver, the remaining kidney tissue and the other gill arches were removed, frozen in liquid nitrogen, and stored at $-80^{\circ} \mathrm{C}$ until analysis of ORD activities and thyroid hormone tissue concentrations. Previous to storage, the liver was weighed and the hepatosomatic index (HSI) calculated as: HSI $(\%)=($ liver wet weight/body wet weight $) \times 100$.

\section{Plasma parameters}

Plasma $\mathrm{Na}^{+}, \mathrm{Cl}^{-}, \mathrm{K}^{+}$, glucose and lactate concentrations were measured using a Stat Profile ${ }^{\circledR}$ pHOx plus analyser (Nova Biomedical, Waltham, MA, USA). Plasma triglycerides were measured using a kit from Spinreact SA (Sant Esteve d'en Bas, Girona, Spain) that was adapted to 96-wells microplates. Plasma non-esterified fatty acids (NEFA) levels were determined with the NEFA-C method (Wako Chemicals, Neuss, Germany), according to the manufacturer's instructions.

Plasma free T3 and T4 (fT3 and fT4, respectively) levels were determined using Wallac DELFIA ${ }^{\circledR}$ solid phase timeresolved fluoroimmunoassay kits (PerkinElmer Life and Analytical Sciences, Turku, Finland). This method was validated for use with $S$. senegalensis blood plasma. Charcoal was used to strip plasma of endogenous thyroid hormones. Validations showed that serial dilutions of untreated plasma diluted with stripped plasma displaced europium-labelled iodothyronine from the antibody in parallel with dilutions of the standards supplied by the manufacturer (results not shown). The assays were conducted according to the manufacturer's instructions, and measured in a Wallac Victor ${ }^{2} 1420$ multilabel counter. Samples were diluted 1:3 (v/v) with charcoal-stripped plasma prior to fT3 determinations. The intra-assay and inter-assay coefficients of variation of the fT3 and fT4 fluoroimmunoassay, as reported by the manufacturer, are 4.9 and $4.6 \%$, and 3.3 and $4.0 \%$, respectively. The reported cross-reactivity of the mouse anti-T3 antibody to L-T4 is $0.2 \%$ (setting the reactivity to L-T3 at $100 \%$ ), and to diiodothyronine $0.86 \%$. The reported cross-reactivity of the mouse anti-T4 antibody to D-T4 is $30.1 \%$ (setting the reactivity to $\mathrm{L}-\mathrm{T} 4$ at $100 \%$ ), and to $\mathrm{L}-\mathrm{T} 3, \mathrm{D}-\mathrm{T} 3$ and diiodothyronine $0.89,0.37$ and $<0.1 \%$, respectively. Cross-reactivities of both antibodies to diiodotyrosine and iodotyrosine are $<0.1 \%$. The reported analytical sensitivities of the fT3 and fT4 fluoroimmunoassay are better than $2 \mathrm{pM}$ for both hormones.

Plasma cortisol was measured by radioimmunoassay as described by Arjona et al. (2008).

\section{$\mathrm{Na}^{+}, \mathrm{K}^{+}$-ATPase activities}

Branchial tissue was obtained by scraping the gill arch with a glass microscope slide and homogenized in $1 \mathrm{ml}$ of ice-cold sucrose buffer $(250 \mathrm{mM}$ sucrose, $1 \mathrm{mM}$ ethylenediamine tetraacetic acid (EDTA), $100 \mathrm{mM}$ trishydroxymethylaminomethane adjusted to $\mathrm{pH} 7.4$ with $\mathrm{HCl}$ ) in a glass Dounce homogenizer equipped with a tightly fitting Teflon pestle. Kidney tissue was homogenized in $0.5 \mathrm{ml}$ of the same buffer. The specific $\mathrm{Na}^{+}-$and $\mathrm{K}^{+}$dependent, ouabain-sensitive ATPase activity was measured in triplicate in gill and kidney homogenates according to the method described by Flik et al. (1983). The method was adapted to a 96-wells microplate format by scaling down the original volumes. Triplicate $5-\mu 1$ aliquots of sucrose-buffer diluted homogenates were incubated for $15 \mathrm{~min}$ at the optimum temperature of $37^{\circ} \mathrm{C}$ (data not shown).

Specific $\mathrm{Na}^{+}, \mathrm{K}^{+}$-ATPase activities at ambient temperature were measured at the water temperature to which each group had acclimated. Here, incubation times were $20 \mathrm{~min}$ at $26^{\circ} \mathrm{C}, 30 \mathrm{~min}$ at $19^{\circ} \mathrm{C}$ and $45 \mathrm{~min}$ at $12^{\circ} \mathrm{C}$. In all reactions, homogenate dilutions were such that substrate (ATP) consumption during the incubation period was less than $15 \%$. We interpret the measurements at the optimum temperature of $37^{\circ} \mathrm{C}$ to reflect the total amount of enzyme present in the homogenate (specific activity at optimal temperature: $\mathrm{SA}_{\text {opt}}$ ) (Metz et al. 2003). The measurements at ambient temperatures are an estimation of the enzyme activity in vivo (specific activity at ambient temperature: $\mathrm{SA}_{\mathrm{amb}}$ ). Specific $\mathrm{Na}^{+}, \mathrm{K}^{+}$-ATPase activities are expressed in $\mu \mathrm{mol}$ liberated inorganic phosphate per min per $\mathrm{mg}$ protein. Protein was measured with a commercial Coomassie Brilliant Blue reagent kit (Bio-Rad Laboratories, München, Germany) using bovine serum albumin (BSA) as a standard. 
Outer ring deiodination (ORD) activities

Liver, gills and kidney were homogenized in phosphate buffer (100 mM Na-phosphate, 2 mM EDTA, pH 7.0). We used the method described by Klaren et al. (2005) to assess ORD activities using reverse T3 (rT3) and T4 as substrates. Reverse T3 is the preferred substrate for many vertebrate deiodinases type 1. Thyroxine (T4) was included in our assays because the deiodination of $\mathrm{T} 4$ to $\mathrm{T} 3$ is the major and physiologically relevant metabolic pathway in the activation of thyroid hormone. The requirements of the rT3- and T4-ORD reactions for dithiothreitol (DTT) in S. senegalensis were determined first. As in S. senegalensis kidney (Arjona et al. 2008), DTT inhibits ORD in all tissues examined (Fig. 1), and we thus excluded DTT from our assay media. ORD activities were assayed in duplicate using 20 to $70 \mu \mathrm{g}$ homogenate protein in $200 \mu \mathrm{l}$ of $100 \mathrm{mM}$ phosphate/2 mM EDTA (pH 7.0) to which were added: $5 \mu \mathrm{M}$ rT3 or T4 (Sigma Chemical Co., St Louis,
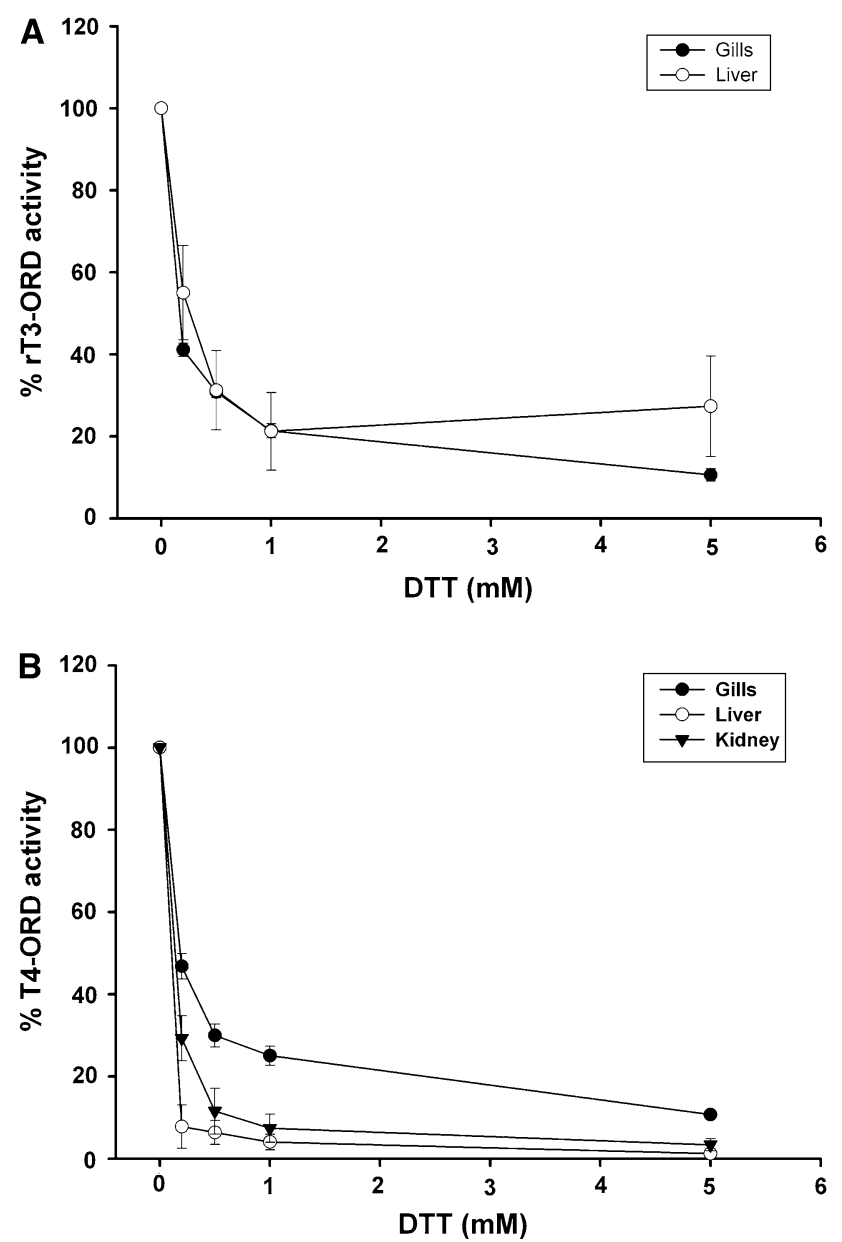

Fig. 1 Effects of DTT on rT3-ORD (a) and T4-ORD (b) activities in gills, liver and kidney of $S$. senegalensis juveniles. rT3-ORD and T4ORD activities are expressed relative to the activity measured in the absence of DTT. Values are expressed as mean $\pm \operatorname{SEM}(n=3)$
MO, USA) and $10^{5} \mathrm{cpm}$ of $\left[{ }^{125} \mathrm{I}\right] \mathrm{rT} 3$ or $\left[{ }^{125} \mathrm{I}\right] \mathrm{T} 4$ (NEN Life Science Products, Inc., Boston, MA, USA). Homogenates were incubated at the optimum assay temperature of $37^{\circ} \mathrm{C}$ (data not shown) for 12 and $15 \mathrm{~min}$ (T4- and rT3-ORD, respectively). The specific ORD activity thus calculated is designated as $\mathrm{SA}_{\text {opt }}$. Homogenates were also incubated for 20,30 and $45 \mathrm{~min}$ at 26,19 and $12^{\circ} \mathrm{C}$, respectively, to determine the specific ORD activity at ambient temperature $\left(\mathrm{SA}_{\mathrm{amb}}\right)$. Substrate utilization was always less than $15 \%$. Radiotracer was purified on a $10 \%$ (w/v) Sephadex LH-20 mini-column shortly before use, as described by Mol and Visser (1985). The specific ORD rate was corrected for non-enzymatic ORD activity that was determined in the absence of sample, and expressed as fmoles rT3 or T4 deiodinated per minute per mg protein. Our calculations included a correction factor of 2 to take into account the random labelling of the $3^{\prime}$ - and $5^{\prime}$-positions of $\left[{ }^{125} \mathrm{I}\right] \mathrm{rT} 3$ and $\left[{ }^{125} \mathrm{I}\right] \mathrm{T} 4$. Protein was measured with a commercial Coomassie Brilliant Blue reagent kit (Bio-Rad Laboratories, München, Germany) using BSA as a standard.

Thyroid hormone tissue concentrations

Thyroid hormones were extracted as described by Tagawa and Hirano (1987). Liver, kidney and gill scrapings (70$450 \mathrm{mg}$ wet weight) were homogenized in $2.5 \mathrm{ml}$ ice-cold 99:1 (v/v) methanol/ammonia containing $1 \mathrm{mM}$ of the iodothyronine deiodinase inhibitor 6 - $n$-propyl-2-thiouracil (PTU), thoroughly mixed for $10 \mathrm{~min}$ at $4^{\circ} \mathrm{C}$ and centrifuged at $2,000 \mathrm{~g}\left(15 \mathrm{~min}, 4^{\circ} \mathrm{C}\right)$. The supernatant was collected, and the procedure was repeated twice. Pooled supernatants were lyophilized overnight at $45^{\circ} \mathrm{C}$ in a freeze dry system. The residues were resuspended in $875 \mu \mathrm{l}$ of a 6:1 (v/v) mixture of chloroform and 99:1 (v/v) methanol/ ammonia including $1 \mathrm{mM}$ PTU, and $125 \mu \mathrm{l}$ barbital buffer (50 mM sodium barbitone in distilled water, $\mathrm{pH}$ 8.6). Samples were shaken for $10 \mathrm{~min}$ at room temperature and the upper phase, which contains the thyroid hormones, was collected and lyophilized at $45^{\circ} \mathrm{C}$. Dried extracts were dissolved in barbital buffer containing $0.1 \%$ BSA and stored at $-20^{\circ} \mathrm{C}$ until thyroid hormone measurements. Total T3 and T4 concentrations were measured in duplicate with a competitive enzyme-linked immunosorbent assay (ELISA) (Human Gesellschaft für Biochemica und Diagnostica $\mathrm{mbH}$, Wiesbaden, Germany) according to the manufacturer's instructions. The intra-assay and interassay coefficients of variation for $\mathrm{T} 3$ and $\mathrm{T} 4$ reported by the manufacturer are 2.6 and $2.4 \%$, and 4.2 and $3.3 \%$, respectively. The reported cross-reactivity of the ovine anti-T3 antibody to L-T4 is $<0.02 \%$ (setting the reactivity to L-T3 at $100 \%$ ). The reported cross-reactivity of the ovine anti-T4 antibody to D-T4 is $98 \%$ (setting the reactivity to L-T4 at 100\%), and to L-T3 and D-T3 is 3 and $1.5 \%$, 
respectively. Cross-reactivities of both antibodies to diiodothyronine, diiodotyrosine and iodotyrosine are $<0.01 \%$. The reported sensitivities of the $\mathrm{T} 3$ and $\mathrm{T} 4$ ELISA are $0.05 \mathrm{ng} / \mathrm{ml} \mathrm{T} 3$ and $4 \mathrm{ng} / \mathrm{ml} \mathrm{T} 4$, respectively. Recovery percentages were calculated from spiked samples and were determined to be $88.6 \pm 4.1$ for T3 and $69.5 \pm 2.1$ for T4 $(n=3$, mean $\pm \mathrm{SEM})$. The assay was validated for use with barbital buffer $(0.1 \%$ BSA $)$ by confirming parallel displacement of serially diluted samples (with barbital buffer) to the standard curve (data not shown). Measurements are corrected for recovery, and final results are presented in $\mathrm{ng} / \mathrm{g}$ wet tissue.

\section{Statistics and calculations}

The effects of exposure to different ambient temperatures $\left(12,19\right.$ and $\left.26^{\circ} \mathrm{C}\right)$ and feeding conditions (fed and non-fed/ fasted) were analysed using a two-way analysis of variance (ANOVA). When appropriate, data were logarithmically transformed to fulfil the requirements for ANOVA (homoscedasticity and normality), but data are shown untransformed for clarity. When significant differences were obtained from the ANOVA, Student's $t$-tests were carried out for paired-comparisons to analyse the effect of: i) feeding, by comparing normally fed fish at $19^{\circ} \mathrm{C}$ vs. fasted fish at $19^{\circ} \mathrm{C}$ (fasting control group) and ii) ambient temperature, comparing non-fed fish at $12^{\circ} \mathrm{C}$ vs. fasted fish at $19^{\circ} \mathrm{C}$ (fasting control group) and normally fed fish at $19^{\circ} \mathrm{C}$ vs. normal fed fish at $26^{\circ} \mathrm{C}$. The significance level was set at $P<0.05$.

Binding data from the fT4 and fT3 assays were transformed by calculating: $\operatorname{logit}\left(\mathrm{B}_{\mathrm{i}} / \mathrm{B}_{0}\right)=\log \left[\left(\mathrm{B}_{\mathrm{i}} / \mathrm{B}_{0}\right) /\right.$ $\left.\left(1-\left(\mathrm{B}_{\mathrm{i}} / \mathrm{B}_{0}\right)\right)\right]$. Here, $\mathrm{B}_{\mathrm{i}}$ represents the europium-labelled iodothyronine binding, and $\mathrm{B}_{0}$ the maximum binding measured in the absence of unlabelled ligand.

\section{Results}

No mortality and pathologies were observed in any experimental group. $P$-values resulting from the two-way ANOVA of all parameters assessed are displayed in Table 1.

Tables 1 and 2 show that feeding regime, not temperature, affects weight gain. Predictably, non-feeding fish in the $12^{\circ} \mathrm{C}$-acclimated group and feed-deprived fish at $19^{\circ} \mathrm{C}$ (fasting control group) did not grow. Changes in HSI did not correlate with changes in body weight, and were affected by both feeding regime and acclimation temperature. Fasting and acclimation to $26^{\circ} \mathrm{C}$ decreased, acclimation to $12^{\circ} \mathrm{C}$ increased HSI. Except for a small, ca. $5 \%$, increase in the $\mathrm{Na}^{+}$concentration in the feed-deprived
Table $1 P$-values from two-way ANOVA of weight gain and parameters measured in gills, kidney and liver of $S$. senegalensis juveniles acclimated to different ambient temperatures and feeding regimes during an experimental period of 3 weeks

\begin{tabular}{|c|c|c|c|}
\hline Tissue & Parameter & Temperature & Feeding \\
\hline & Weight gain & NS & 0.002 \\
\hline \multirow[t]{10}{*}{ Plasma } & $\mathrm{Na}^{+}$ & 0.009 & $<0.001$ \\
\hline & $\mathrm{Cl}^{-}$ & NS & NS \\
\hline & $\mathrm{K}^{+}$ & NS & NS \\
\hline & Glucose & $<0.001$ & NS \\
\hline & Lactate & 0.001 & $<0.001$ \\
\hline & Triglyceride & $<0.001$ & $<0.001$ \\
\hline & NEFA & $<0.001$ & NS \\
\hline & fT3 & $<0.001$ & NS \\
\hline & fT4 & $<0.001$ & $<0.001$ \\
\hline & Cortisol & NS & NS \\
\hline \multirow[t]{7}{*}{ Liver } & HSI & $<0.001$ & 0.024 \\
\hline & $\mathrm{T} 3$ & 0.028 & NS \\
\hline & $\mathrm{T} 4$ & 0.002 & 0.010 \\
\hline & rT3ORD SA opt & NS & $<0.001$ \\
\hline & rT3ORD SA ${ }_{a m b}$ & 0.023 & 0.002 \\
\hline & T4ORD SA $\mathrm{opt}_{\mathrm{ot}}$ & NS & $<0.001$ \\
\hline & T4ORD SA $\mathrm{amb}_{\mathrm{a}}$ & 0.046 & 0.007 \\
\hline \multirow[t]{8}{*}{ Kidney } & $\mathrm{Na}^{+}, \mathrm{K}^{+}$-ATPase $\mathrm{SA}_{\mathrm{opt}}$ & $<0.001$ & $<0.001$ \\
\hline & $\mathrm{Na}^{+}, \mathrm{K}^{+}$-ATPase $\mathrm{SA}_{\mathrm{amb}}$ & $<0.001$ & $<0.001$ \\
\hline & $\mathrm{T} 3$ & NS & NS \\
\hline & $\mathrm{T} 4$ & 0.020 & $<0.001$ \\
\hline & rT3ORD SA ${ }_{o p t}$ & 0.002 & NS \\
\hline & rT3ORD SA $\mathrm{amb}_{\mathrm{a}}$ & 0.011 & NS \\
\hline & T4ORD SA $\mathrm{opt}_{\mathrm{o}}$ & 0.003 & NS \\
\hline & T4ORD SA ${ }_{\mathrm{amb}}$ & NS & NS \\
\hline \multirow[t]{8}{*}{ Gills } & $\mathrm{Na}^{+}, \mathrm{K}^{+}$-ATPase $\mathrm{SA}_{\mathrm{opt}}$ & NS & NS \\
\hline & $\mathrm{Na}^{+}, \mathrm{K}^{+}$-ATPase $\mathrm{SA}_{\mathrm{amb}}$ & $<0.001$ & NS \\
\hline & $\mathrm{T} 3$ & NS & NS \\
\hline & $\mathrm{T} 4$ & NS & NS \\
\hline & rT3ORD SA $\mathrm{opt}_{\mathrm{o}}$ & NS & $<0.001$ \\
\hline & rT3ORD SA ${ }_{a m b}$ & NS & 0.009 \\
\hline & T4ORD SA opt & NS & 0.017 \\
\hline & T4ORD SA $\mathrm{amb}_{\mathrm{m}}$ & $<0.001$ & $<0.001$ \\
\hline
\end{tabular}

Ambient temperature and feeding regime (fed and non-fed/fasted) are the main factors

$N S$ not significant

$(P>0.05)$

group kept at $19^{\circ} \mathrm{C}$, plasma electrolytes were not affected by temperature or feeding.

Acclimation to $12^{\circ} \mathrm{C}$ notably increased plasma concentrations of triglycerides and NEFA. This temperature effect can be distinguished from a fasting effect, as the feeddeprived animals held at $19^{\circ} \mathrm{C}$ had plasma triglyceride and 
Table 2 Weight gain, HSI and plasma levels of electrolytes, metabolites (glucose, lactate, triglycerides and NEFA) and hormones (fT3, fT4, cortisol) in S. senegalensis juveniles acclimated to different ambient temperatures and feeding regimes during an experimental period of 3 weeks

\begin{tabular}{|c|c|c|c|c|c|}
\hline $\begin{array}{l}\text { Temperature } \\
\text { Feeding }\end{array}$ & $\begin{array}{l}12^{\circ} \mathrm{C} \\
-\end{array}$ & $\begin{array}{l}19^{\circ} \mathrm{C} \\
-\end{array}$ & $\begin{array}{l}19^{\circ} \mathrm{C} \\
+\end{array}$ & $\begin{array}{l}26^{\circ} \mathrm{C} \\
+\end{array}$ & Significance \\
\hline Weight gain $(\%)$ & $-1.6 \pm 6.7$ & $-2.5 \pm 5.5$ & $27.6 \pm 6.4$ & $24.9 \pm 7.5$ & $19^{\circ} \mathrm{C}(-)$ vs. $19^{\circ} \mathrm{C}(+)^{\# \#}$ \\
\hline HSI (\%) & $1.21 \pm 0.11$ & $0.78 \pm 0.10$ & $1.05 \pm 0.04$ & $0.80 \pm 0.06$ & $\begin{array}{l}19^{\circ} \mathrm{C}(-) \text { vs. } 19^{\circ} \mathrm{C}(+)^{\#} \\
12^{\circ} \mathrm{C}(-) \text { vs. } 19^{\circ} \mathrm{C}(-)^{* *} \\
19^{\circ} \mathrm{C}(+) \text { vs. } 26^{\circ} \mathrm{C}(+)^{* *}\end{array}$ \\
\hline \multicolumn{6}{|l|}{ Electrolytes } \\
\hline $\mathrm{Na}^{+}(\mathrm{mM})$ & $157 \pm 2$ & $165 \pm 1$ & $156 \pm 1$ & $156 \pm 2$ & $\begin{array}{l}19^{\circ} \mathrm{C}(-) \text { vs. } 19^{\circ} \mathrm{C}(+)^{\# \#} \\
12^{\circ} \mathrm{C}(-) \text { vs. } 19^{\circ} \mathrm{C}(-)^{* * *}\end{array}$ \\
\hline $\mathrm{Cl}^{-}(\mathrm{mM})$ & $135 \pm 5$ & $135 \pm 2$ & $132 \pm 2$ & $132 \pm 1$ & \\
\hline $\mathrm{K}^{+}(\mathrm{mM})$ & $3.4 \pm 0.19$ & $3.3 \pm 0.09$ & $3.0 \pm 0.07$ & $3.3 \pm 0.05$ & \\
\hline \multicolumn{6}{|l|}{ Metabolites } \\
\hline Glucose (mM) & $5.7 \pm 0.3$ & $4.5 \pm 0.1$ & $5.0 \pm 0.1$ & $5.8 \pm 0.2$ & $\begin{array}{l}12^{\circ} \mathrm{C}(-) \text { vs. } 19^{\circ} \mathrm{C}(-)^{* *} \\
19^{\circ} \mathrm{C}(+) \text { vs. } 26^{\circ} \mathrm{C}(+)^{*}\end{array}$ \\
\hline Lactate (mM) & $2.9 \pm 0.3$ & $1.9 \pm 0.1$ & $3.1 \pm 0.08$ & $3.1 \pm 0.3$ & $\begin{array}{l}19^{\circ} \mathrm{C}(-) \text { vs. } 19^{\circ} \mathrm{C}(+)^{\# \# \#} \\
12^{\circ} \mathrm{C}(-) \text { vs. } 19^{\circ} \mathrm{C}(-)^{* *}\end{array}$ \\
\hline Triglycerides $(\mathrm{mM})$ & $23.3 \pm 2.4$ & $1.5 \pm 0.1$ & $7.4 \pm 1.4$ & $4.3 \pm 0.9$ & $\begin{array}{l}19^{\circ} \mathrm{C}(-) \text { vs. } 19^{\circ} \mathrm{C}(+)^{\# \# \#} \\
12^{\circ} \mathrm{C}(-) \text { vs } 19^{\circ} \mathrm{C}(-)^{* * *}\end{array}$ \\
\hline NEFA (mM) & $1.0 \pm 0.13$ & $0.3 \pm 0.02$ & $0.5 \pm 0.08$ & $0.3 \pm 0.04$ & $12^{\circ} \mathrm{C}(-)$ vs. $19^{\circ} \mathrm{C}(-)^{* * *}$ \\
\hline \multicolumn{6}{|l|}{ Hormones } \\
\hline Free T3 (pM) & $21.7 \pm 1.9$ & $33.9 \pm 1.9$ & $37.2 \pm 1.6$ & $32.7 \pm 2.3$ & $12^{\circ} \mathrm{C}(-)$ vs. $19^{\circ} \mathrm{C}(-)^{* * *}$ \\
\hline Free T4 (pM) & $11.9 \pm 1.2$ & $11.4 \pm 1.6$ & $25.8 \pm 1.2$ & $15.1 \pm 1.4$ & $\begin{array}{l}19^{\circ} \mathrm{C}(-) \text { vs. } 19^{\circ} \mathrm{C}(+)^{\# \#} \\
19^{\circ} \mathrm{C}(+) \text { vs. } 26^{\circ} \mathrm{C}(+)^{* * *}\end{array}$ \\
\hline Cortisol (ng/ml) & $8.1 \pm 2.1$ & $8.1 \pm 3.6$ & $14.4 \pm 4.6$ & $6.8 \pm 2.0$ & \\
\hline
\end{tabular}

Data are expressed as mean \pm SEM $\left(n=9-10\right.$ per group). Pound signs indicate significant differences attributed to feeding regime $\left({ }^{\#} P<0.05\right.$,

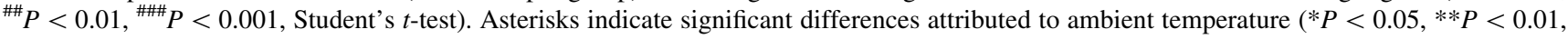
$* * * P<0.001$, Student's $t$-test)

NEFA concentrations that were lower and comparable respectively to the normally fed fish.

Plasma cortisol levels were highly variable in the different groups. Both ambient temperature and feeding regime did not cause statistically significant differences. Free T3 levels had decreased in $12^{\circ} \mathrm{C}$-acclimated fishes (comparing the $12^{\circ} \mathrm{C} /$ non-fed group with the $19^{\circ} \mathrm{C} /$ fasted group). Highest plasma levels of T4 were measured in the feeding group kept at $19^{\circ} \mathrm{C}$. In all other groups, T4 levels had decreased by 41 to $56 \%$, indicating distinct effects of fasting and high-temperature acclimation $\left(26^{\circ} \mathrm{C}\right)$.

No significant changes in tissue $\mathrm{T} 3$ and $\mathrm{T} 4$ levels in the gills were observed (Table 3). In the kidney, highest T4 levels were measured in the normally fed animals kept at $19^{\circ} \mathrm{C}$, compared to their controls that were fasted and kept at $26^{\circ} \mathrm{C}$, respectively.

Compared to kidney and gills, thyroid hormone concentrations in the liver varied with temperature and feeding regime (Table 3). Lowest liver T3 concentrations were measured in animals acclimated to $12^{\circ} \mathrm{C}$. This effect could not be attributed to non-feeding, since the fasting control group and the normally fed fish (both kept at $19^{\circ} \mathrm{C}$ ) showed similar values. Hepatic T4 was affected by both ambient temperature and feeding regime. Lowering the temperature from 19 to $12^{\circ} \mathrm{C}$ in the fasting c.q. non-feeding groups, or from 26 to $19^{\circ} \mathrm{C}$ in the normally feeding groups resulted in a ca. two-fold increase in hepatic T4 levels.

Maximum branchial $\mathrm{Na}^{+}, \mathrm{K}^{+}$-ATPase activities assayed at the optimum temperature of $37^{\circ} \mathrm{C}\left(\mathrm{SA}_{\text {opt }}\right)$ were not significantly affected by feeding regime or acclimation temperature (Fig. 2a). However, when measured at the acclimation temperature of the fish, $\mathrm{SA}_{\mathrm{amb}}$ increased with increasing acclimation temperature. In the kidney, fasting elicited a decrease in $\mathrm{SA}_{\text {opt }}$ and $\mathrm{SA}_{\mathrm{amb}}$ of $\mathrm{Na}^{+}, \mathrm{K}^{+}$-ATPase at $19^{\circ} \mathrm{C}$ (Fig. 2b). When acclimated to the lowest temperature of $12^{\circ} \mathrm{C}, \mathrm{SA}_{\text {opt }}$ increased compared with the fasting control group at $19^{\circ} \mathrm{C}$. Acclimation to the highest temperature tested $\left(26^{\circ} \mathrm{C}\right)$ only affected $\mathrm{SA}_{\mathrm{amb}}$.

T4- and rT3-ORD activities responded similarly to the experimental treatments (Figs. 3 and 4), and thus probably reflect the same enzymatic component. In liver and gills, animals acclimated to the lowest temperature of $12^{\circ} \mathrm{C}$ 
Table 3 Total T4 and T3 concentrations in liver, kidney and gills, expressed per gram of wet tissue weight, in S. senegalensis juveniles acclimated to different ambient temperatures and feeding regimes during a period of 3 weeks

\begin{tabular}{|c|c|c|c|c|c|}
\hline $\begin{array}{l}\text { Temperature } \\
\text { Feeding }\end{array}$ & $\begin{array}{l}12^{\circ} \mathrm{C} \\
-\end{array}$ & $\begin{array}{l}19^{\circ} \mathrm{C} \\
-\end{array}$ & $\begin{array}{l}19^{\circ} \mathrm{C} \\
+\end{array}$ & $\begin{array}{l}26^{\circ} \mathrm{C} \\
+\end{array}$ & Significance \\
\hline \multicolumn{6}{|l|}{ Liver } \\
\hline T3 (ng/g liver) & $15.2 \pm 2.2$ & $36.5 \pm 8.0$ & $31.5 \pm 3.6$ & $39.5 \pm 5.7$ & $12^{\circ} \mathrm{C}(-)$ vs. $19^{\circ} \mathrm{C}(-)^{*}$ \\
\hline T4 (ng/g liver) & $23.9 \pm 3.5$ & $13.6 \pm 1.9$ & $24.0 \pm 2.8$ & $12.7 \pm 1.3$ & $\begin{array}{l}19^{\circ} \mathrm{C}(-) \text { vs. } 19^{\circ} \mathrm{C}(+)^{\#} \\
12^{\circ} \mathrm{C}(-) \text { vs. } 19^{\circ} \mathrm{C}(-)^{*} \\
19^{\circ} \mathrm{C}(+) \text { vs. } 26^{\circ} \mathrm{C}(+)^{* *}\end{array}$ \\
\hline \multicolumn{6}{|l|}{ Kidney } \\
\hline T3 (ng/g kidney) & $14.0 \pm 2.1$ & $15.3 \pm 1.3$ & $19.0 \pm 2.3$ & $18.0 \pm 1.3$ & \\
\hline T4 (ng/g kidney) & $9.2 \pm 2.5$ & $6.1 \pm 1.8$ & $18.2 \pm 1.8$ & $9.9 \pm 1.7$ & $\begin{array}{l}19^{\circ} \mathrm{C}(-) \text { vs. } 19^{\circ} \mathrm{C}(+)^{\# \#} \\
19^{\circ} \mathrm{C}(+) \text { vs. } 26^{\circ} \mathrm{C}(+)^{*}\end{array}$ \\
\hline \multicolumn{6}{|l|}{ Gills } \\
\hline T3 (ng/g gills) & $1.1 \pm 0.2$ & $2.4 \pm 0.8$ & $1.7 \pm 0.2$ & $2.0 \pm 0.3$ & \\
\hline T4 (ng/g gills) & $3.9 \pm 1.1$ & $8.5 \pm 3.0$ & $6.6 \pm 2.2$ & $7.6 \pm 2.3$ & \\
\hline
\end{tabular}

Data are expressed as mean $\pm \operatorname{SEM}(n=5$ per group). See the legend to Table 2 for an explanation of the symbols used

displayed the highest $\mathrm{SA}_{\mathrm{opt}}$ deiodinase activities. However, this increase was attributed to non-feeding as increased activities were measured in fasted animals compared to normally fed fish kept at $19^{\circ} \mathrm{C}$. In the kidney, $\mathrm{SA}_{\text {opt }}$ was also the highest when animals were acclimated to $12^{\circ} \mathrm{C}$, but here, this effect could be specifically attributed to temperature as fasting had no significant effect (see Table 1). In kidney, despite differences in the maximal ORD activities $\left(\mathrm{SA}_{\mathrm{opt}}\right)$ attributed to temperature, rT3- and T4-ORD activities measured at the acclimation temperature, $\mathrm{SA}_{\mathrm{amb}}$, remained remarkably stable.

\section{Discussion}

Effects of ambient temperature

Changes in temperature are known to impair osmoregulatory ability in several teleostean species (Salmo salar: Staurnes et al. 2001; Cyprinus carpio: Metz et al. 2003; Oreochromis mossambicus: Fiess et al. 2007). As judged from the unchanged plasma electrolyte concentrations, S. senegalensis can still ionoregulate adequately at different ambient temperatures. The total enzymatic expression of branchial $\mathrm{Na}^{+}, \mathrm{K}^{+}$-ATPase does not respond to different acclimation temperatures, as the specific activities measured at optimum temperature did not change. The correlation between branchial $\mathrm{Na}^{+}, \mathrm{K}^{+}$-ATPase activities measured at ambient temperature $\left(\mathrm{SA}_{\mathrm{amb}}\right)$ and incubation temperature can then simply be explained from Arrhenius' law that describes the effect of temperature on reaction rate constants.

In order to maintain ionic equilibrium between the plasma and ambient water compartments during cold acclimation, an imbalance between passive flows and primary active transport can be compensated by acclimation strategies that increase ion pump capacity, i.e. $\mathrm{Na}^{+}, \mathrm{K}^{+}-$ ATPase (Schwarzbaum et al. 1991, 1992; Metz et al. 2003), or decrease membrane permeability to ions (Hochachka 1988a, b). Our data indicate that both strategies are employed by S. senegalensis in an organ-specific manner. Total $\mathrm{Na}^{+}, \mathrm{K}^{+}$-ATPase activities $\left(\mathrm{SA}_{\text {opt }}\right)$ in the gills did not respond to changes in acclimation temperature, and this could hint at a passive osmoregulatory strategy that reduces electrolyte permeability of gill plasma membranes. The reduced ATP demand by decreased branchial $\mathrm{Na}^{+}, \mathrm{K}^{+}$-ATPase activities in vivo could result in a lower energy expenditure at low temperatures, and can perhaps give physiological relevance to the inhibited appetite of S. senegalensis at $12^{\circ} \mathrm{C}$. In contrast, in kidney, temperature-induced decrease in enzyme activity is compensated by an up-regulation of the total enzymatic expression of the renal $\mathrm{Na}^{+}, \mathrm{K}^{+}$-ATPase (measured as $\mathrm{SA}_{\text {opt }}$ ). As a result $\mathrm{Na}^{+}, \mathrm{K}^{+}$-ATPase activity in vivo $\left(\mathrm{SA}_{\mathrm{amb}}\right)$ is maintained at the same level measured at $19^{\circ} \mathrm{C}$ (fasted animals).

Most conspicuous is the mobilization of triglycerides and NEFA, together with the increased HSI in S. senegalensis juveniles at $12^{\circ} \mathrm{C}$. In other eurythermal and euryhaline teleosts as Sparus aurata, cold acclimation is characterized by lipid deposition in liver as a result of high liver uptake of circulating lipids from peripheral fat (Ibarz et al. 2007). The high HSI of S. senegalensis reflects an increase in hepatic mass, which can be interpreted as an increase in energy storage. Together with the mobilization of triglycerides/NEFA, this points to deposition of lipids in the liver of $12^{\circ} \mathrm{C}$-acclimated $S$. senegalensis juveniles. 

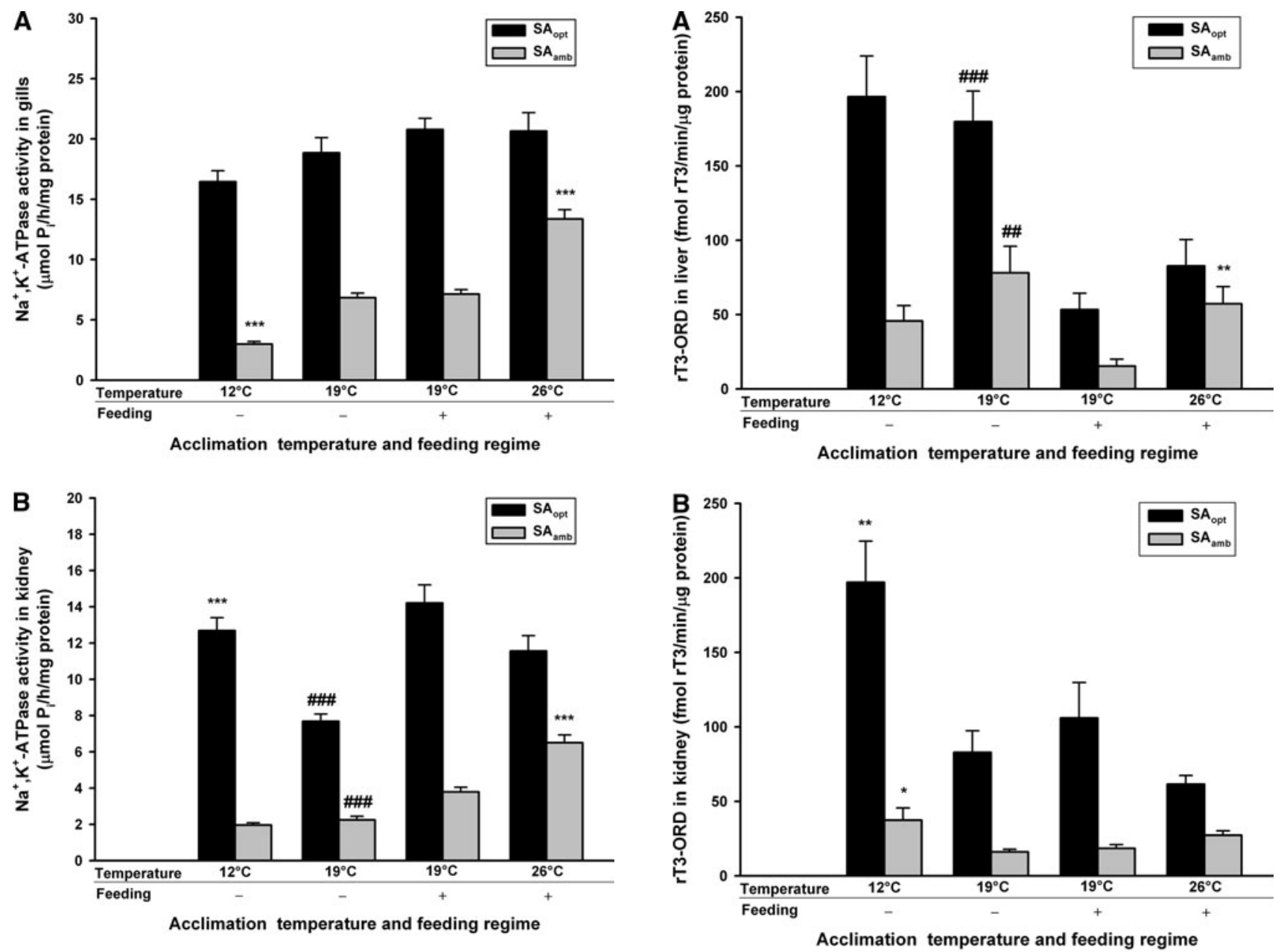

Fig. 2 Effects of different ambient temperatures and feeding regimes on branchial (a) and renal (b) $\mathrm{Na}^{+}, \mathrm{K}^{+}$-ATPase activities of S. senegalensis after 21 days of exposure. Black bars indicate $\mathrm{Na}^{+}, \mathrm{K}^{+}$-ATPase activities in tissue homogenates incubated at the optimum assay temperature $\left(\mathrm{SA}_{\mathrm{opt}}\right)$ and grey bars those activities when tissue homogenates were incubated at the ambient temperature where each group acclimated $\left(\mathrm{SA}_{\mathrm{amb}}\right)$. Values are mean \pm SEM $(n=9-10$ per group). Pound signs indicate significant differences attributed to feeding regime $\left({ }^{\#} P<0.05,{ }^{\# \#} P<0.01,{ }^{\# \# \#} P<0.001\right.$, Student's $t$-test). Asterisks indicate significant differences attributed to ambient temperature $(* P<0.05, * * P<0.01, * * * P<0.001$, Student's $t$-test $)$

In fish, cortisol has both mineralocorticoid and glucocorticoid activities (Mommsen et al. 1999; McCormick 2001). In C. carpio, rising temperatures induce an increase in basal plasma cortisol levels (Arends et al. 1998; Metz et al. 2003; van den Burg et al. 2003). The same pattern has been observed in Acanthopagrus schlegeli (Choi et al. 2007). In contrast, when $S$. senegalensis was allowed to acclimate to a similar range of temperatures plasma cortisol levels did not change. Cortisol is an important hormone in the stress response, and as a glucocorticoid is involved in energy metabolism. The increased plasma cortisol concentrations that follow changes in temperature can be interpreted as to allow the animal to cope with extra

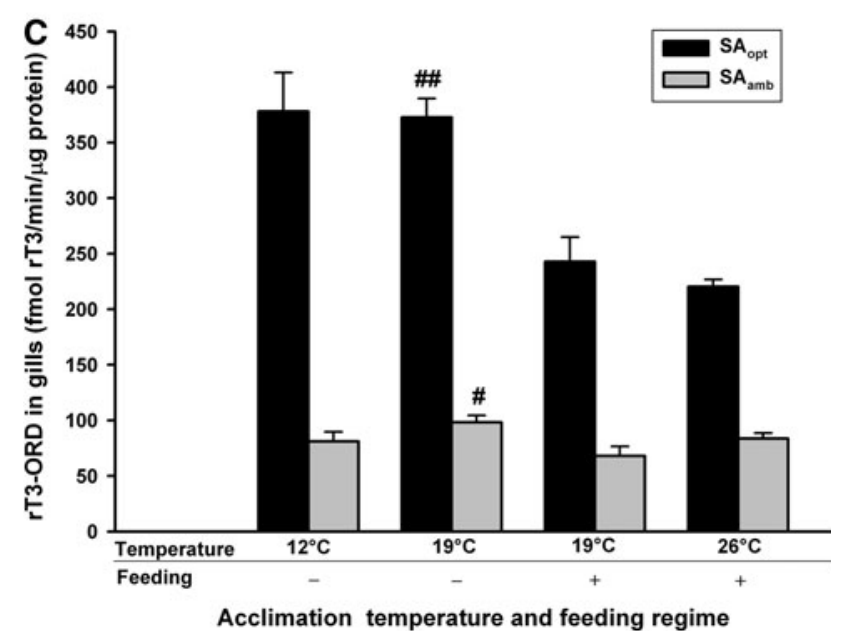

Fig. 3 Effects of different ambient temperatures and feeding regimes on rT3-ORD activities in liver (a), kidney (b) and gills (c) of S. senegalensis after 21 days of exposure. Black bars indicate rT3-ORD activities in tissue homogenates incubated at the optimum assay temperature $\left(\mathrm{SA}_{\mathrm{opt}}\right)$ and grey bars those activities when tissue homogenates were incubated at the ambient temperature where each group acclimated $\left(\mathrm{SA}_{\mathrm{amb}}\right)$. Values are mean $\pm \operatorname{SEM}(n=5$ per group). See the legend to Fig. 2 for an explanation of the symbols used 

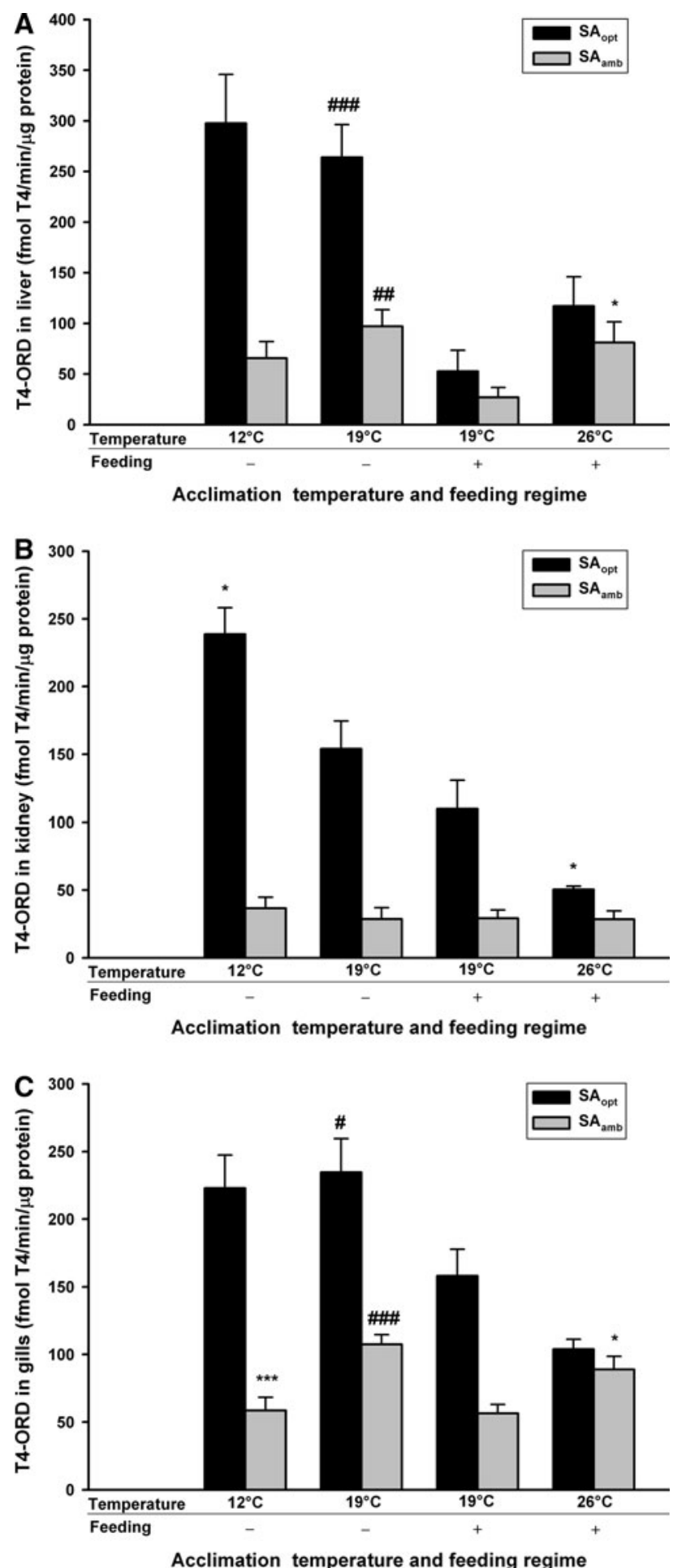

Fig. 4 Effects of different ambient temperatures and feeding regimes on T4-ORD activities in liver (a), kidney (b) and gills (c) of S. senegalensis after 21 days of exposure. Black bars indicate T4-ORD activities in tissue homogenates incubated at the optimum assay temperature $\left(\mathrm{SA}_{\mathrm{opt}}\right)$ and grey bars those activities when tissue homogenates were incubated at the ambient temperature where each group acclimated $\left(\mathrm{SA}_{\mathrm{amb}}\right)$. Values are mean \pm SEM $(n=5$ per group). See the legend to Fig. 2 for an explanation of the symbols used energetic requirements during acclimation to higher temperatures. Whereas osmotic challenges clearly evoke a stress response in S. senegalensis (Arjona et al. 2007, 2008) that results in an allostatic state (McEwen and Wingfield 2003), changes in temperature do not. It could be that the metabolic alterations induced by changes in ambient temperature do not require the development of a new allostatic state in S. senegalensis. On the other hand, hormones other than cortisol, e.g. thyroid hormones, could play a central role in temperature acclimation.

Apart from the relationships between temperature and the magnitude of physical-chemical rate constants, some physiological processes yet may still require secondary adjustments to altered key enzyme activities. Fish also must have thus developed adequate acclimation strategies to cope with varying ambient temperatures (Somero 2004). The responses of ORD activities to changes in ambient temperature observed in kidney suggest an increase in the total concentration of deiodinases (measured as $\mathrm{SA}_{\text {opt }}$ ) with decreasing temperatures in order to compensate for the lower activities measured at the ambient acclimation temperature $\left(\mathrm{SA}_{\mathrm{amb}}\right)$.

The correlation between plasma fT3 levels and hepatic T3 concentrations in $S$. senegalensis led us to hypothesize that the T3 generated in the liver is exported to the plasma, while in osmoregulatory tissues such as kidney and gills, locally produced $\mathrm{T} 3$ will bind to receptors in the same cell. The relevance of lowered plasma fT3 levels at $12^{\circ} \mathrm{C}$ may be to adjust the metabolic rate to the lower energy demands imposed by low temperatures. When we consider hepatic $\mathrm{T} 4$ and $\mathrm{T} 3$ concentrations, the respective $\mathrm{T} 3 / \mathrm{T} 4$ ratios were 0.6 for non-feeding fish kept at $12^{\circ} \mathrm{C}$ and 2.7 for the fasted fish kept at $19^{\circ} \mathrm{C}$. This indicates that the conversion of $\mathrm{T} 4$ into $\mathrm{T} 3$ is favoured at $19^{\circ} \mathrm{C}$ compared with $12^{\circ} \mathrm{C}$ under non-feeding/fasting conditions. However, both groups showed, in liver, similar concentrations of ORD-deiodinases (measured as $\mathrm{SA}_{\text {opt }}$ ) that yielded similar ORD rates at ambient temperature (measured as $\mathrm{SA}_{\mathrm{amb}}$ ). It should be mentioned that apart from the ORD pathway, other reactions that are also integrated in the peripheral metabolism of thyroid hormones, e. g. inner ring deiodination, sulfation or glucoronidation, can affect thyroid hormone intracellular levels. So, it is entirely feasible that these pathways different than ORD are affected by temperature. Then, they could be the source of discrepancy between hepatic T3/T4 ratios in $12^{\circ} \mathrm{C}$ - and $19^{\circ} \mathrm{C}$-acclimated (fasted) fish when ORD activities in vivo $\left(\mathrm{SA}_{\mathrm{amb}}\right)$ are statistically the same in both conditions.

\section{Effect of fasting}

One interesting fact observed in this study was that S. senegalensis stops feeding when acclimated to $12^{\circ} \mathrm{C}$. 
We have observed that fasting alters osmoregulatory capacity in $S$. senegalensis, reflected by lowered renal $\mathrm{Na}^{+}, \mathrm{K}^{+}$-ATPase activity $\left(\mathrm{SA}_{\text {opt }}\right.$ and $\left.\mathrm{SA}_{\mathrm{amb}}\right)$.

In several fish species, as in higher vertebrates, plasma triglyceride levels decline with the suppression of lipogenic enzyme activities (Zammit and Newsholme 1979; Iritani et al. 1986; Santulli et al. 1997; Pérez-Jiménez et al. 2007). In $S$. senegalensis, the changes in plasma triglyceride concentrations suggest a down-regulation of lipogenesis during feed deprivation, probably with the aim to preserve plasma glucose levels (Navarro and Gutiérrez 1995). Furthermore, the HSI of the Senegalese sole was distinctly lower in fasted animals kept at the same temperature of $19^{\circ} \mathrm{C}$, indicating mobilization of hepatic storage. Liver acts as the main glycogen reserve, so it is feasible that during fasting, mobilization of glucose from glycogen contributed to maintain plasma euglycemia, as was observed in other eurythermal and euryhaline teleosts (Polakof et al. 2006).

Our data show that feed deprivation also influences the thyroidal system in the Senegalese sole. Specifically, fasting evoked an up-regulation of the total amount of deiodinases with ORD capacity (measured as $\mathrm{SA}_{\mathrm{opt}}$ ) in liver and gills. Moreover, changes in plasma fT4 levels correlated with $\mathrm{T} 4$ tissue concentration in liver, and can be explained by the twofold increase in hepatic ORD assayed at the ambient temperature $\left(\mathrm{SA}_{\mathrm{amb}}\right.$, estimation of ORD rate in vivo).

\section{Conclusions}

In conclusion, changes in ambient water temperature elicit osmoregulatory and thyroidal responses in S. senegalensis that can be interpreted to meet the altered requirements of metabolic and osmoregulatory systems under different temperatures. These responses include a decrease in circulating T3 and organ-specific compensatory strategies to counteract the effects of cold temperature on enzyme rates. To determine to what extent thyroid hormones are involved in the process of temperature acclimation in S. senegalensis, further research is warranted in order to establish how these hormones alter cellular metabolic activity.

\footnotetext{
Acknowledgments The authors acknowledge the anonymous reviewers that have participated in the evaluation of this manuscript, their comments and suggestions have been very helpful. The authors are also very grateful to Planta de Cultivos Marinos (C.A.S.E.M., Universidad de Cádiz, Puerto Real, Cádiz, Spain) for providing experimental fish. This study was partly supported by grants AGL2007-61211/ACU (Ministerio de Ciencia e Innovación and FEDER, Spain) and Proyecto de Excelencia PO7-RNM-02843 (Junta de Andalucía) to J.M. Mancera. Francisco J. Arjona is funded by Ministerio de Ciencia e Innovación (Spain) through the program "Formación de Profesorado Universitario" (Ref: AP-2004-6829).
}

Open Access This article is distributed under the terms of the Creative Commons Attribution Noncommercial License which permits any noncommercial use, distribution, and reproduction in any medium, provided the original author(s) and source are credited.

\section{References}

Arends RJ, van der Gaag R, Martens GJM, Wendelaar Bonga SE, Flik G (1998) Differential expression of two pro-opiomelanocortin mRNAs during temperature stress in common carp (Cyprinus carpio L.). J Endocrinol 159:85-91

Arjona FJ, Vargas-Chacoff L, Ruiz-Jarabo I, Martín del Río MP, Mancera JM (2007) Osmoregulatory response of Senegalese sole (Solea senegalensis, Kaup 1858) to changes in environmental salinity. Comp Biochem Physiol A 148:413-421

Arjona FJ, Vargas-Chacoff L, Martín del Río MP, Flik G, Mancera JM, Klaren PHM (2008) The involvement of thyroid hormones and cortisol in the osmotic acclimation of Solea senegalensis. Gen Comp Endocrinol 155:796-803

Binner M, Kloas W, Hardewig I (2008) Energy allocation in juvenile roach and burbot under different temperature and feeding regimes. Fish Physiol Biochem 34:103-116

Campbell CM, Davies PS (1975) Thermal acclimation in the teleost, Blennius pholis (L). Comp Biochem Physiol A 52:147-151

Choi CY, Min BH, Jo PG, Chang YJ (2007) Molecular cloning of PEPCK and stress response of black porgy (Acanthopagrus schlegeli) to increased temperature in freshwater and seawater. Gen Comp Endocrinol 152:47-53

Couto A, Enes P, Peres H, Oliva-Teles A (2008) Effect of water temperature and dietary starch on growth and metabolic utilization of diets in gilthead sea bream (Sparus aurata) juveniles. Comp Biochem Physiol A 151:45-50

Cyr DG, Idler DR, Audet C, McLeese JM, Eales JG (1998) Effects of long-term temperature acclimation on thyroid hormone deiodinase function, plasma thyroid hormone levels, growth, and reproductive status of male Atlantic cod, Gadus morhua. Gen Comp Endocrinol 109:24-36

Eales JG (1985) The peripheral metabolism of thyroid hormones and regulation of thyroidal status in poikilotherms. Can $\mathrm{J}$ Zool 63:1217-1231

Eales JG (2006) Modes of action and physiological effects of thyroid hormones in fish endocrinology. Science Publishers, Inc., Enfield, pp 767-808

Eales JG, Brown SB (1993) Measurement and regulation of thyroidal status in teleost fish. Rev Fish Biol Fish 3:299-347

Enes P, Panserat S, Kaushik S, Oliva-Teles A (2008) Rearing temperature enhances hepatic glucokinase but not glucose-6phosphatase activities in European sea bass (Dicentrarchus labrax) and gilthead sea bream (Sparus aurata) juveniles fed with the same level of glucose. Comp Biochem Physiol A 150:355-358

Evans DH (2002) Cell signalling and ion transport across the fish gill epithelium. J Exp Zool 293:336-347

Fiess JC, Kunkel-Patterson A, Mathias L, Riley LG, Yancey PH, Hirano T, Grau EG (2007) Effects of environmental salinity and temperature on osmoregulatory ability, organic osmolytes, and plasma hormone profiles in the Mozambique tilapia (Oreochromis mossambicus). Comp Biochem Physiol A 146:252-264

Flik G, Wendelaar Bonga SE, Fenwick JC (1983) $\mathrm{Ca}^{2+}$-dependent phosphatase and ATPase activities in eel gill plasma membranes. I. Identification of $\mathrm{Ca}^{2+}$-activated ATPase activities with non-specific phosphatase activities. Comp Biochem Physiol B $76: 745-754$ 
Goldspink G (1995) Adaptation of fish to different environmental temperature by qualitative and quantitative changes in gene expression. J Therm Biol 20:167-174

Handeland SO, Imsland AK, Stefansson SO (2008) The effect of temperature and fish size on growth, feed intake, food conversion efficiency and stomach evacuation rate of Atlantic salmon postsmolts. Aquaculture 283:36-42

Hochachka PW (1988a) Channels and pumps-Determinants of metabolic cold adaptation strategies. Comp Biochem Physiol B 3:515-519

Hochachka PW (1988b) Metabolic-, channel-, and pump-coupled functions: constraints and compromises of coadaptation. Can J Zool 66:1015-1027

Ibarz A, Beltrán M, Fernández-Borràs J, Gallardo MA, Sánchez J, Blasco J (2007) Alterations in lipid metabolism and use of energy depots of gilthead sea bream (Sparus aurata) at low temperatures. Aquaculture 262:470-480

Imsland AK, Björnsson BT, Gunnarsson S, Foss A, Stefansson SO (2007) Temperature and salinity effects on plasma insulin-like growth factor-I concentrations and growth in juvenile turbot (Scophthalmus maximus). Aquaculture 271:546-552

Iritani N, Nagashima K, Fukuda H, Katsurada A, Tanaka T (1986) Effects of dietary proteins on lipogenic enzymes in rat liver. J Nutr 116:190-197

Klaren PHM, Haasdijk R, Metz JR, Nitsch LMC, Darras VM, Van der Geyten S, Flik G (2005) Characterization of an iodothyronine $5^{\prime}$-deiodinase in gilthead seabream (Sparus auratus) that is inhibited by dithiothreitol. Endocrinology 146:5621-5630

Klaren PHM, Geven EJW, Flik G (2007) The involvement of the thyroid gland in teleost osmoregulation. In: Baldisserotto B, Mancera JM, Kapoor BG (eds) Fish osmoregulation. Science Publishers, Enfield, pp 35-65

Lynshiang DS, Gupta BB (2000) Role of thyroidal and testicular hormones in regulation of tissue respiration in male air-breathing fish, Clarias batrachus (Linn.). Indian J Exp Biol 38:705-712

Marshall WS, Grosell M (2005) Ion transport, osmoregulation and acid-base balance. In: Evans DH, Claiborne JB (eds) Physiology of fishes. CRC Press, Boca Raton, pp 177-230

McCormick SD (2001) Endocrine control of osmoregulation in teleost fish. Integr Comp Biol 41:781-794

McEwen BS, Wingfield JC (2003) The concept of allostasis in biology and biomedicine. Horm Behav 43:2-15

Metz JR, van den Burg EH, Wendelaar Bonga SE, Flik G (2003) Regulation of branchial $\mathrm{Na}^{+} / \mathrm{K}^{+}$-ATPase in common carp Cyprinus carpio L. acclimated to different temperatures. J Exp Biol 206:2273-2280

Mol JA, Visser TJ (1985) Synthesis and some properties of sulfate esters and sulfamates of iodothyronines. Endocrinology 117:1-7

Mommsen TP, Vijayan MM, Moon TW (1999) Cortisol in teleosts: dynamics, mechanisms of action, and metabolic regulation. Rev Fish Biol Fish 9:211-268

Navarro I, Gutiérrez J (1995) Fasting and starvation. In: Hochachka PW, Mommsen TP (eds) Biochemistry and molecular biology of fishes. Elsevier, Amsterdam, pp 393-434
Pérez-Jiménez A, Guedes MJ, Morales AE, Oliva-Teles A (2007) Metabolic responses to short starvation and refeeding in Dicentrarchus labrax. Effect of dietary composition. Aquaculture 265:325-335

Peter MCS, Oommen OV (1989) Oxidative metabolism in a teleost, Anabas testudineus Bloch: effect of thyroid hormones on hepatic enzyme activities. Gen Comp Endocrinol 73:96-107

Polakof S, Arjona FJ, Sangiao-Alvarellos S, Martín del Río MP, Mancera JM, Soengas JL (2006) Food deprivation alters osmoregulatory and metabolic responses to salinity acclimation in gilthead sea bream Sparus auratus. J Comp Physiol B 1-12

Santulli A, Messina CM, D'Amelio V (1997) Variations of lipid and apolipoprotein content in lipoproteins during fasting in European sea bass (Dicentrarchus labrax L.). Comp Biochem Physiol A 118:1233-1239

Sardella BA, Kültz D, Cech JJ, Brauner CJ (2008) Salinity-dependent changes in $\mathrm{Na}^{+} / \mathrm{K}^{+}$-ATPase content of mitochondria-rich cells contribute to differences in thermal tolerance of Mozambique tilapia. J Comp Physiol B 178:249-256

Schwarzbaum PJ, Wieser W, Niederstätter H (1991) Contrasting effects of temperature acclimation on mechanisms of ionic regulation in an eurythermic and a stenothermic species of freshwater fish (Rutilus rutilus and Salvelinus alpinus). Comp Biochem Physiol A 98:483-489

Schwarzbaum PJ, Wieser W, Cossins AR (1992) Species-specific responses of membranes and the $\mathrm{Na}^{+}+\mathrm{K}^{+}$pump to temperature change in the kidney of two species of freshwater fish, roach (Rutilus rutilus) and Artic char (Salvelinus alpinus). Physiol Zool 65:17-34

Somero GN (2004) Adaptation of enzymes to temperature: searching for basic "strategies". Comp Biochem Physiol B 139:321-333

Staurnes M, Sigholt T, Asgard T, Baeverfjord G (2001) Effects of a temperature shift on seawater challenge test performance in Atlantic salmon (Salmo salar) smolt. Aquaculture 201:153-159

Tagawa M, Hirano T (1987) Presence of thyroxine in eggs and changes in its content during early development of chum salmon, Oncorhynchus keta. Gen Comp Endocrinol 68:129-135

van den Burg EH, Metz JR, Ross HA, Darras VM, Wendelaar Bonga SE, Flik G (2003) Temperature-induced changes in thyrotropinreleasing hormone sensitivity in carp melanotropes. Neuroendocrinology 77:15-23

van Ham EH, Berntssen MHG, Imsland AK, Parpoura AC, Wendelaar Bonga SE, Stefansson SO (2003) The influence of temperature and ration on growth, feed conversion, body composition and nutrient retention of juvenile turbot (Scophthalmus maximus). Aquaculture 217:547-558

Vinagre C, Fonseca V, Cabral H, Costa MJ (2006) Habitat suitability index models for the juvenile soles, Solea solea and Solea senegalensis, in the Tagus estuary: defining variables for species management. Fish Res 82:140-149

Zammit VA, Newsholme EA (1979) Activities of enzymes of fat and ketone-body metabolism and effects of starvation on blood concentrations of glucose and fat fuels in teleost and elasmobranch fish. Biochem J 184:313-322 